\title{
Recovery of Proteins as a Spun Product from Sardine Viscera and Heads
}

\author{
Munehiko TanaKa, Kōsaku SuzuKI, and Takeshi TAGUCHI*
}

(Accepted March 3, 1983)

\begin{abstract}
To recover proteins as a spun product from sardine viscera and heads for the use of food ingredient, factors affecting the extraction of proteins were investigated. Factors examined were extraction time, temperature, $\mathrm{NaCl}$ concentration, and effect of $\mathrm{pH}$. The most appropriate extraction was made by water at $22^{\circ} \mathrm{C}$ for $30 \mathrm{~min}$ at $\mathrm{pH} 10.5$ (final value). In order to concentrate proteins, the extracted proteins were precipitated out by adjusting the $\mathrm{pH}$ to 5.0 , and the precipitates were dissolved in $\mathrm{NaOH}$ solution for the preparation of spinning dope. The coagulation solution containing $20 \% \mathrm{NaCl}$ or $20 \% \mathrm{CaCl}_{2}$ in $1 \mathrm{~N}$ acetic acid gave $40-59 \%$ recovery of proteins in spun products. On the other hand, a spun product prepared by using $1 \mathrm{~N}$ acetic acid in ethanol brought about $70 \%$ protein recovery and its lipid content was fairly low.
\end{abstract}

Recently there has been an increasing interest in the use of underutilized fish species, such as sardines and mackerels, which are caught near the coasts of Japan in large quantities. However, more than $50 \%$ of these fish species are used for non-human outlets, the most important of which is for animal feed as fish meal. ${ }^{1)}$ Although a large amount of fish industry wastes such as viscera and head portions themselves are unsuitable for human consumption, their protein quality is substantially equivalent to that of fish muscle proteins. ${ }^{2-4)}$ Therefore, it would be important to recover proteins from fish wastes with acceptable properties as a food ingredient, because there has been a shortage of proteins with high biological value in the world. While fish protein concentrate (FPC) has been developed for this purpose, it usually lacks the functional properties of water-holding and gel-forming abilities. Consequently, it has limited application for food use. Spinning of vegetable proteins such as soybean proteins has been intensively studied, ${ }^{5,6}$ ) but there is a scarcity of information available concerning the spinning of fish proteins. $^{1)}$

The purpose of this study was to develop the recovery technique of proteins from sardine viscera and heads as a spun product.

\section{Materials and Methods}

Sample

Sardines Sardinops melanosticta were used throughout this study. The average body weight and length of the sample fish were $107 \mathrm{~g}$ and $22 \mathrm{~cm}$, respectively. Head portions were cut off at the edge of operculum. The average weight of the viscera was $14 \mathrm{~g}$, corresponding $13 \%$ of the total body weight, while that of the head was $20 \mathrm{~g}$, which comprised approximately $19 \%$ of the total body weight. The proximate compositions of viscera and heads are given in Table 1.

\section{Extraction and Recovery of Proteins from Viscera and Heads}

Vescera and heads were minced by a Waring blender for $2 \mathrm{~min}$ and $5 \mathrm{~g}$ of minced sample was stirred with $50 \mathrm{ml}$ of the extraction solution. Sodium chloride solutions $(0 \mathrm{M}-1.0 \mathrm{M})$ were used for the extraction and their $\mathrm{pH}$ values were adjusted to 1-12. The final $\mathrm{pH}$ value of the extract was measured. The extraction was carried out at $15^{\circ}, 22^{\circ}, 30^{\circ}$, and $40^{\circ} \mathrm{C}$ for up to $90 \mathrm{~min}$.

After the extraction with $\mathrm{NaCl}$ solutions, they were centrifuged at $7,000 \times \mathrm{g}$ for $15 \mathrm{~min}$ at $4^{\circ} \mathrm{C}$ and the precipitates were discarded. Total nitrogen and TCA soluble nitrogen contents in the supernatants were determined by the Kjeldahl method. The supernatants were then filtered through a glass wool to remove solidified fats, and $\mathrm{pH}$ values of the filtrates were adjusted to 5.0 with $1.0 \mathrm{M} \mathrm{HCl}$ or $1.0 \mathrm{M} \mathrm{NaOH}$ in order to precipitate proteins. After centrifugation at 14,000 $\times \mathrm{g}$ for $20 \mathrm{~min}$ at $4^{\circ} \mathrm{C}$, the precipitates were collected (simply called protein isolate hereafter). Total nitrogen contents of protein isolates obtained

* Department of Food Engineering and Technology, Tokyo University of Fisheries, Konan, Minato, Tokyo 108, Japan（田中宗彦・鈴木康策・田口武：東京水産大学食品工学科）。 
were determined by the Kjeldahl method.

\section{Spinning of Protein Isolates}

The protein isolates obtained as described above were used for the preparation of the spinning dopes. Sodium hydroxide solution was added to the protein isolate to have $\mathrm{NaOH} /$ protein ratio (weight base) of $0.02-0.15$, and the protein concentration of the resulting spinning dope was adjusted to $40-80 \mathrm{mg} / \mathrm{g}$.

After the spinning dopes were thoroughly mixed, they were placed into a syringe with a stainless spinneret (diameter: $0.8 \mathrm{~mm}$ ). The spinning dope was extruded into a coagulation solution. As a coagulation solution, $5-20 \% \mathrm{NaCl}$ in $1 \mathrm{~N}$ acetic acid, $20 \% \mathrm{CaCl}_{2}$ in $1 \mathrm{~N}$ acetic acid, and $1 \mathrm{~N}$ acetic acid in ethanol were used in this study. The spun fibers were removed from the coagulation solution and left to drain of excess coagulation solution. After air-dried at room temperature overnight, solid, protein, lipid and ash contents of the spun products were analyzed.

\section{Results and Discussion}

\section{Extractability of Proteins}

Fig. 1 shows the effect of $\mathrm{NaCl}$ concentration on the extractability of proteins from viscera and heads at $\mathrm{pH} 2,7.5$, and 10.5 (final value). In the case of viscera, protein extractability remarkably decreased with increasing $\mathrm{NaCl}$ concentration at $\mathrm{pH} 2$, while the effect of $\mathrm{NaCl}$ concentration was not so significant at $\mathrm{pH} 7.5$ and 10.5. It was shown that the extraction by water was most suitable for viscera. On the other hand, the protein extractability of head portions was lower over the range of $\mathrm{NaCl}$ concentrations and $\mathrm{pH}$ values tested in this study than that of viscera. The higher recovery of proteins from heads was obtained in the lower concentration of $\mathrm{NaCl}$ except at pH 7.5 , where $0.4 \mathrm{M} \mathrm{NaCl}$ brought about a slightly higher extraction. The difference between the total $\mathrm{N}$ and protein $\mathrm{N}$ was larger in viscera than in heads, indicating the occurrence of protein hydrolysis by digestive enzymes present in viscera.

Fig. 2 illustrates the effect of extraction temperature and time on the protein extraction by water from sardine viscera. The extraction was carried out at $15^{\circ}, 22^{\circ}, 30^{\circ}$, and $40^{\circ} \mathrm{C}$ at $\mathrm{pH} 2,7.5$, and 10.5 (final value). At almost all conditions the total $\mathrm{N}$ extractability reached $80 \%$ within 30 min of extraction, whereas the protein $\mathrm{N}$ extractability decreased with longer extraction time, especially at higher temperatures at $\mathrm{pH} 7.5$ and 10.5. It is apparent from these results that this decrease was concomitant with an autolysis of viscera proteins by the digestive enzymes. The higher recovery of the protein $\mathrm{N}$ was attained by the extraction at $22^{\circ} \mathrm{C}$ for $30 \mathrm{~min}$ at $\mathrm{pH} 10.5$.

The influence of extraction temperature and time on the protein extraction from sardine heads is given in Fig. 3. The extraction of proteins from heads was carried out either by water at $\mathrm{pH} 2$ and 10.5 or by $0.4 \mathrm{M} \mathrm{NaCl}$ at $\mathrm{pH} 7.5$. Both the total $\mathrm{N}$ and protein $\mathrm{N}$ extractabilities were,

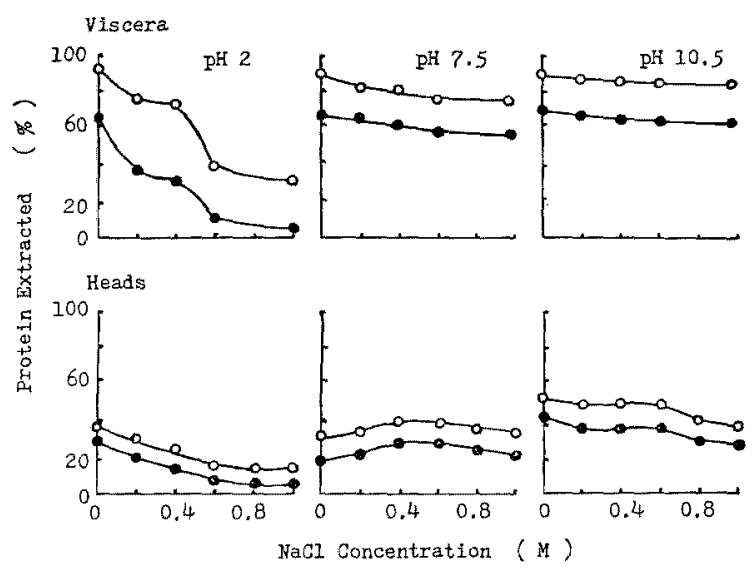

Fig. 1. Effect of $\mathrm{NaCl}$ concentration on the extractability of proteins from sardine viscera and heads. The extraction was carried out at $22^{\circ} \mathrm{C}$ for $30 \mathrm{~min}$. $\mathrm{pH}$ indicated is the final value of the extract.

-O-: Total N,

-.-: Protein N. 


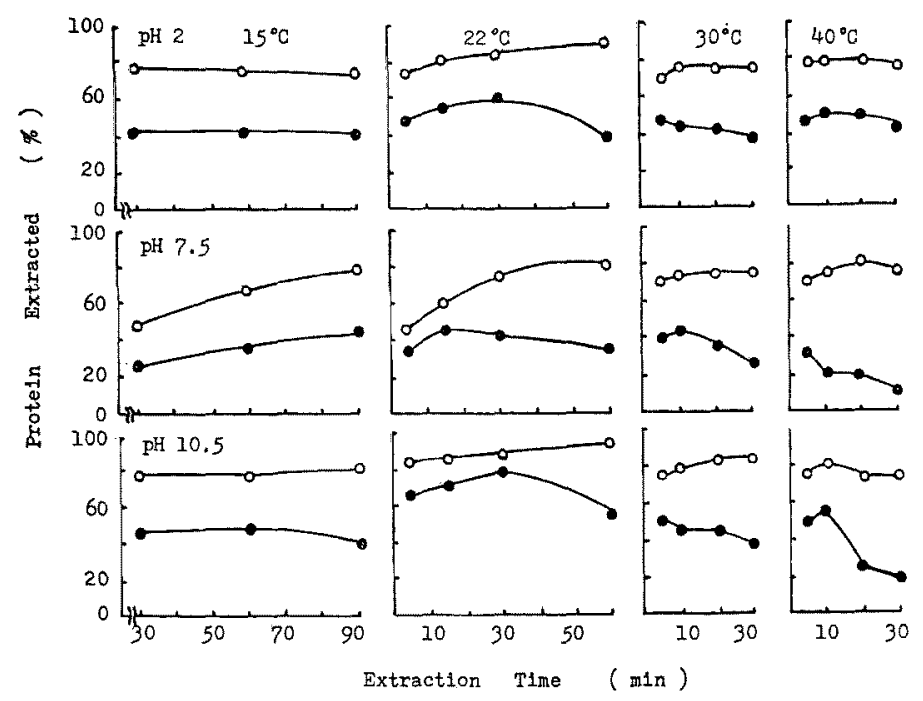

Fig. 2. Effect of extraction temperature and time on the extractability of proteins from sardine viscera. Extraction was carried out by water and $\mathrm{pH}$ indicated is the final value of the extract.

--: Total N, - - : Protein N.

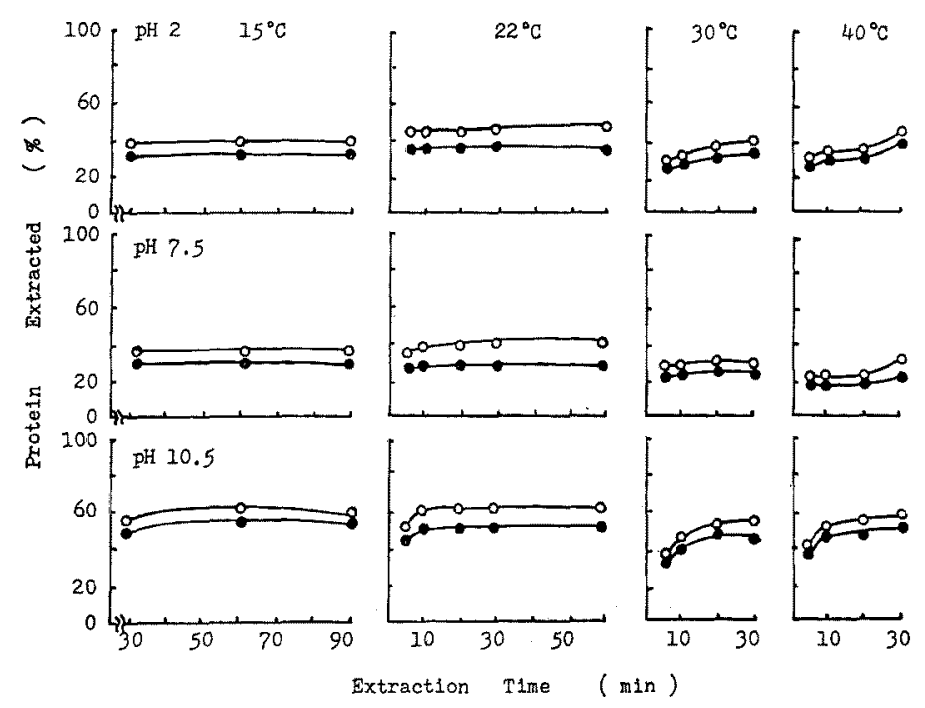

Fig. 3. Effect of extraction temperature and time on the extractability of proteins from sardine heads. Extraction was carried out by water except at $\mathrm{pH} 7.5$ by $0.4 \mathrm{M} \mathrm{NaCl}$, and $\mathrm{pH}$ indicated is the final value of the extract.

--: Total N, - - Protein N.

on the whole, lower in heads than those in viscera at any extraction conditions. Moreover, the difference between the total $\mathrm{N}$ and protein $\mathrm{N}$ extractability in the head portion was quite small, suggesting that the infuence of digestive enzymes on the protein extraction was negligible.
Fig. 4 presents the effect of $\mathrm{pH}$ on the extraction of proteins from sardine viscera and heads at $22^{\circ} \mathrm{C}$. In the case of viscera, as much as $90 \%$ of the total $\mathrm{N}$ and $60 \%$ of the protein $\mathrm{N}$ were extractable at the alkali range regardless of the extraction sohution used. Sodium chloride greatly 


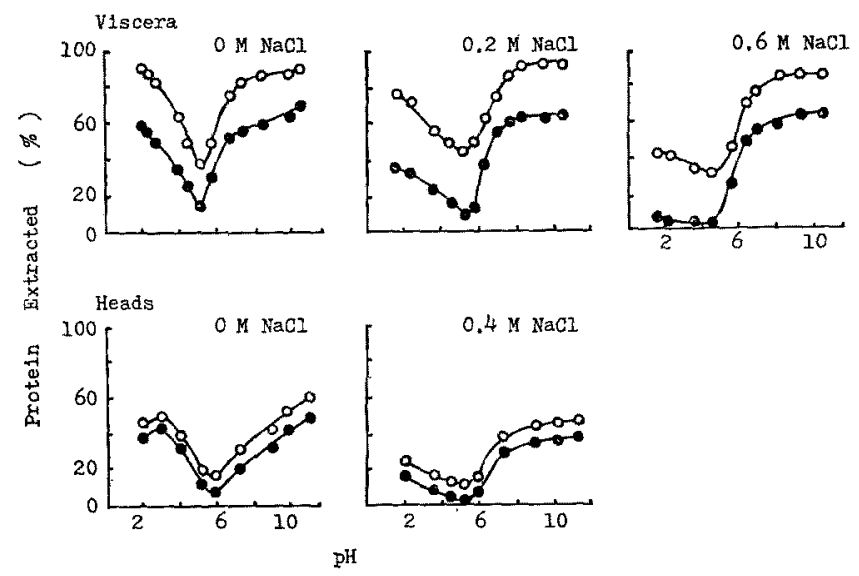

Fig. 4. Effect of $\mathrm{pH}$ on the extractability of proteins from sardine viscera and heads. The extraction was carried out at $22^{\circ} \mathrm{C}$ for $30 \mathrm{~min}$.

-O-: Total N, - - Protein N.
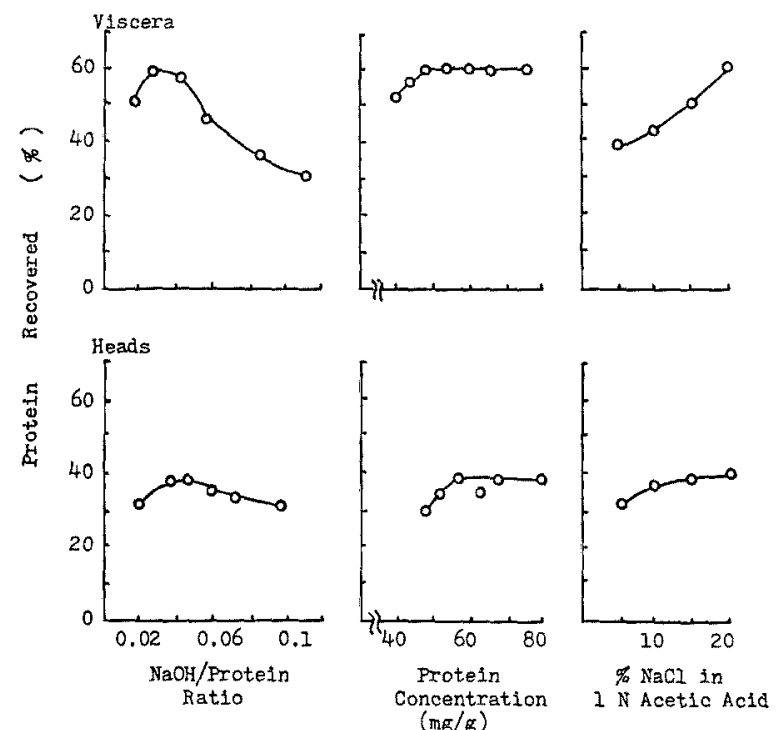

Fig. 5. Effects of $\mathrm{NaOH} /$ protein ratio, protein concentration, $\mathrm{NaCl}$ concentration in the coagulation solution on the recovery of proteins in spun products.

inhibited the extraction of proteins at lower $\mathrm{pH}$ values. As the $\mathrm{pH}$ was altered toward the isoelectric point of around 5.0, the extractability of the protein $\mathbf{N}$ decreased to reach a minimal value of $4-15 \%$. Similar findings have been reported by several investigators. 1,7,8) An analogous result was obtained in sardine heads, but the protein extractability was smaller at any $\mathrm{pH}$ values than that in viscera.

Though a high recovery of proteins from sardine viscera and heads was obtained by the extraction with weak alkali solution as indicated above, the extracts themselves were not concentrated enough for spinning. It was, therefore, necessary to introduce a concentration step prior to the spinning process to give spun products of adequate strength. ${ }^{1)}$ The simplest and most effective procedure for this purpose was to precipitate proteins by adjusting the $\mathrm{pH}$ of the extracts to the isoelectric point, pH 5.0 (Fig. 4). The precipitates thus obtained were dissolved in dilute $\mathrm{NaOH}$ solution to prepare the spinning dope. 


\section{Spinning of Proteins}

Fig. 5 shows the effects of $\mathrm{NaOH} /$ protein ratio, protein concentration of the spinning dope, and the $\mathrm{NaCl}$ concentration in the coagulation solution on the recovery of proteins in spun products. The recovery of proteins decreased with increasing $\mathrm{NaOH} /$ protein ratio and the ratio of around 0.03 was most suitable. The protein recovery in spun products was higher from the viscera dope than that from heads dope. The recovery approached a plateau at the dope protein concentration of $45 \mathrm{mg} / \mathrm{g}$ for viscera and $55 \mathrm{mg} / \mathrm{g}$ for heads. It is apparent from Fig. 5 that the recovery of proteins increased with increasing $\mathrm{NaCl}$ concentration in $1 \mathrm{~N}$ acetic acid solution. The effect of $\mathrm{NaCl}$ concentration on the protein recovery was more significant for viscera dope compared to that for heads dope. The spinning conditions employed for viscera and heads dopes were as follows; $\mathrm{NaOH} /$ protein ratio: 0.028 and 0.035 ,

Table 1. Proximate compositions of spun products from sardine viscera and heads $(\%)$

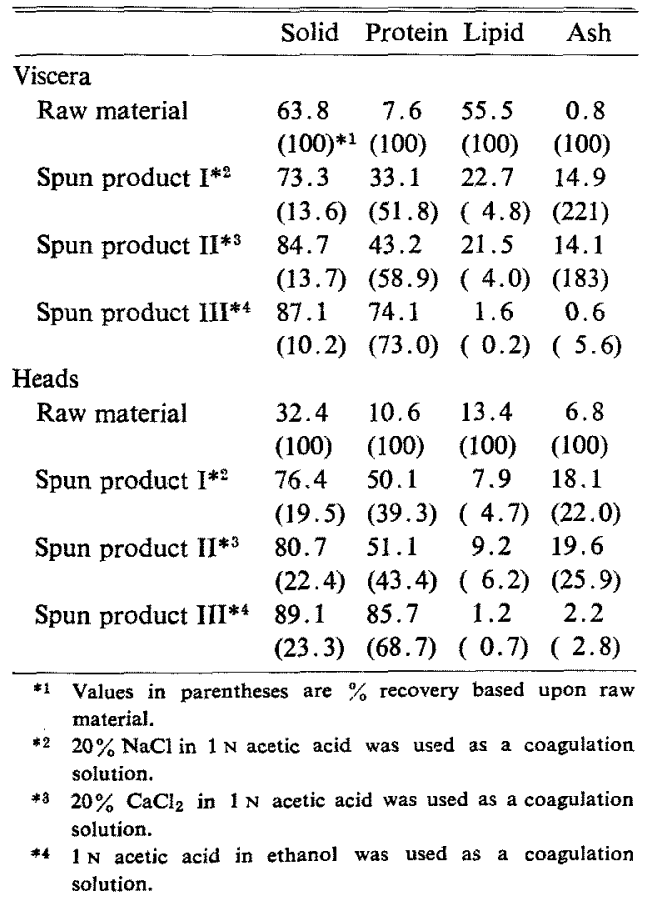

protein concentration: 48 and $55 \mathrm{mg} / \mathrm{g}$, coagulation solution: $20 \% \mathrm{NaCl}$ in $1 \mathrm{~N}$ acetic acid, respectively. The proximate compositions of the spun products thus prepared were determined and the recovery of each component was calculated (spun product $\mathrm{I}$ in Table 1). About $50 \%$ and $40 \%$ of proteins were recovered from viscera and heads, respectively. Ash content of the product remarkably increased due to the use of $\mathrm{NaCl}$ in the coagulation solution.

The spun product II was prepared by substituting $\mathrm{CaCl}_{2}$ for $\mathrm{NaCl}$ in the coagulation solution. Recovery of each component was almost equivalent to that in the spun product $I$. In order to remove lipids as much as possible during the spinning process, $1 \mathrm{~N}$ acetic acid in ethanol was used as the coagulation solution (spun product III). The lipid content of the spun product III was significantly reduced whereas the protein content increased. Using ethanol in the coagulation solution appears to be appropriate for the preparation of spun products from sardine viscera and heads as far as the economical feasibility is not considered. It is revealed from this study that extraction, concentration and coagulation are the important steps for the preparation of spun products from sardine viscera and heads.

\section{References}

1) I. M. Mackie and B. W. Thomson: J. Food Technol., 17, 483-498 (1982).

2) T. Strøm and B. O. EgGum: J. Sci. Food Agric., 32, 115-120 (1981).

3) J. Olley, J. E. Ford, and A. P. Williams: $J$. Sci. Food Agric., 19, 282-285 (1968).

4) W. Tarky, O. P. Agarwala, and G. M. Pigott: J. Food Sci., 38, 917-920 (1973).

5) S. J. Circle and A. K. SMITH: Soybeans: Chemistry and Technology, AVI, Westport, 1972, pp. 216-217.

6) R. E. Feeney and J. R. Whitaker: Food Proteins: Improvement through Chemical and Enzymatic Modification, American Chemical Society, Washington, D.C., 1977, pp. 50-52.

7) W. I. DYer, H. V. FReNCH, and J. M. SNOW: $J$. Fish. Res. Bd. Canada, 7, 585-588 (1950).

8) R. H. Young and R. A. LAwRIE: J. Food Technol., 9, 69-78 (1974). 